\title{
Development of Oil Palm Water Balance Tool for Predicting Water Content Distribution in Root Zone
}

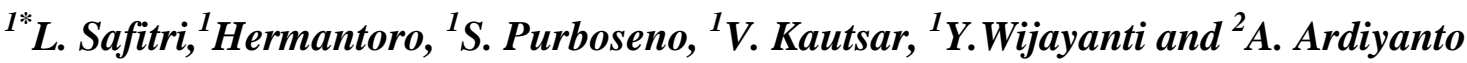 \\ ${ }^{1}$ Institut Pertanian Stiper, Yogyakarta, Indonesia \\ ${ }^{2}$ Research Centre of PT Bumitama Gunajaya Agro, Pundu, Indonesia \\ Email: lisma.safitri86@gmail.com
}

\begin{abstract}
The water content distribution in root zone of oil palm crop is substantial for predicted the crop water usage both for productivity and environmental issues. The varying condition of climate, soil properties, crop stage, ground water existing of oil palm cultivation require the specific water balance analysis model which can evidence the precision condition of water content in root zone. The oil palm water balance tool was developed by inputting the data base including climate, soil properties, crop stage, root density and root zone layer as well. The data was generated through the reference evapotranspiration process by Penman Monteith equation, set parameter of van - genuchten and water flow analysis by Richard equation to bring about the output data in hourly time step which consisted of ETo, soil moisture, cumulative drainage flux, cumulative capillary flux and cumulative water content - rainfall in three root zone. The first, second and third root zone were determined variously depend on the type of soil and the crop stage. The model was built based on the data observation on field research conducted in 3 different condition; the type of soil inceptisol free drainage (without capillary), spodosol with no flux bottom and ultisol with groundwater contribution.
\end{abstract}

Indexed Terms-Water Balance;Oil Palm;Water Content;Root Zone

\section{INTRODUCTION}

The water content distribution in root zone of oil palm crop is substantial for predicting the crop water usage both for productivity and environmental issues. The varying condition of climate, soil properties, crop stage, ground water existing of oil palm cultivation require the specific water balance analysis model which can evidence the precision condition of water content in root zone. The work presented here is a first step to build a simple and robust model of oil palm hydrological behavior, in order to be used to assist the oil palm water footprint which represented the crop water usage of oil palm. The oil palm water footprint analysis model could been used hereafter as an early warning system of palm oil drought as well as means of optimizing palm oil production.

To analyze the distribution of water content in the root zone, the Richards equation approach that illustrates the flow of water in an unsaturated zone can be applied. According to Yuan (2005) [1] the analytical solution to find out the vertical flow in the unsaturation zone and the rooted ground can be known through Richard's equation by knowing the distribution of the main pressures, Water content, fluid flow for the roots, the homogeneity of the soil with various flux variations. This analytical solution can also be used to predict the distribution of water content and flux from water. Philip (1957) [2] and Gardner (1958) [3] explain that Richard's analytical solutions (1931) can be various mathematical expressions used to determine the distribution of water flow in the saturation zone. The analytical solution of Richard's equations with depth terminology to know the absorption of water by the roots is more difficult to do. This is because there are factors of root depth, water content, and salinity that must be known mathematical equations [4]. Muallem (1976) [5] undertook the development of the latest model to predict hydraulic conductivity in the axis zone of unsaturated media. The muallem uses the moisture content curve and measures the 
value of hydraulic conductivity under saturation conditions. This method was developed to determine residuals in water and to extrapolate on moisture content curves within a limited range.

The oil palm water balance tool was developed by inputting the data base including climate, soil properties, crop stage, root density and root zone layer as well. The data was generated through the reference evapotranspiration process by Penman Monteith equation, set parameter of Van Genuchten and water flow analysis by Richard equation to bring about the output data in hourly time step which consisted of ETo, soil moisture, cumulative drainage flux, cumulative capillary flux and cumulative water content - rainfall in three root zone.

The first, second and third root zone were determined variously depend on the type of soil and the crop stage (Table 2). The model was built based on the data observation on field research conducted in 3 different condition; the type of soil inceptisol free drainage (without capillary), spodosol with no flux bottom and ultisol with groundwater contribution.

\section{METHODOLOGY}

\subsection{Data Input of the model}

The model was built based on the data observation on field research conducted in 3 different condition; the type of soil inceptisol free drainage (without capillary), spodosol with no flux bottom and ultisol with groundwater contribution. Input data consist of rainfall and climate observation data from Automatic Weather Station on the Pundu Oil Palm Plantation, Central Borneo, with time step of 15 minutes and data series of 2 months (4 April - 4 June 2017).

The variation of parameter in this oil palm water balance model are soil properties. Van genuchten parameter is vary for each soil type. Root depth zone is chategorized by its root distribution and root density, also by other specific characteristics and condition of availability of ground water contribution for each soil condition.

The data input of this model generally consisted of 3 types of data:

1. Climate data

It is a series of hourly climate data (rainfall, temperature, relative humidity, wind speed, and solar radiation) taken from Automatic Weather Station in Pantai Mas Estate (Appendix 1)

2. The soil properties data

Soil types in oil palm plantation in Pundu, Central Borneo consist of 3 different soil types including inceptisol, spodosol and ultisol (see Table 1). In order to run the Richard equation [6], optimization of the van genuchten [7-8] parameter was performed, and the result are shown in Table 1.

\section{The crop properties}

It includes the value of crop coefficient $(\mathrm{Kc})$ and root density. 
Table 1: Soil properties and Van Genuchten parameters

\begin{tabular}{|c|c|c|c|c|}
\hline \multicolumn{2}{|c|}{ Soil Type } & Ultisol & Spodosol & Inceptisol \\
\hline \multicolumn{2}{|c|}{$\begin{array}{l}\text { Sand } \\
(\%)\end{array}$} & 33.30 & 89.29 & 52.38 \\
\hline \multicolumn{2}{|c|}{$\begin{array}{l}\text { Silt } \\
(\%)\end{array}$} & 30.32 & 3.44 & 16.24 \\
\hline \multicolumn{2}{|c|}{$\begin{array}{c}\text { Loam } \\
(\%)\end{array}$} & 36.39 & 7.28 & 31.38 \\
\hline \multicolumn{2}{|c|}{$\begin{array}{l}\text { Bulk Density } \\
\left(\mathrm{g} / \mathrm{cm}^{3}\right)\end{array}$} & 1.33 & 1.42 & 1.38 \\
\hline \multicolumn{2}{|c|}{$\begin{array}{c}\text { Porosity } \\
(\%)\end{array}$} & 49.91 & 46.59 & 47.86 \\
\hline \multicolumn{2}{|c|}{$\begin{array}{c}\mathrm{Ks} \\
(\mathrm{Cm} / \mathrm{Hour})\end{array}$} & 10.31 & 36.49 & 8.24 \\
\hline \multirow{4}{*}{ Vg Paramaters } & $\theta \mathrm{s}$ & 0.439 & 0.404 & 0.418 \\
\hline & $\theta \mathrm{r}$ & 0.142 & 0.147 & 0.169 \\
\hline & alpha & 0.011 & 0.009 & 0.011 \\
\hline & $n$ & 1.356 & 1.821 & 1.605 \\
\hline
\end{tabular}

\subsection{Rainfall and climate input data}

The local rainfall data in Pundu area within 5 days is utilized as input data (see Figure 1). Rainfall depth distribution ranges between $0-8 \mathrm{~mm} /$ hour. Climate data input within 5 days also applied which consist of temperature, relative humidity, solar radiation and wind speed (Figure 2 and 3). Temperature and relative humidity ranges between $22.5-36.4{ }^{\circ} \mathrm{C}$ with average of $27.3^{\circ} \mathrm{C}$ and ,50.4$100 \%$ with average of $88.5 \%$, respectively. Solar radiation and wind speed ranges between $0-4.2$ $\mathrm{MJ} / \mathrm{mm} /$ hours and $0-2 \mathrm{~m} / \mathrm{s}$, respectively.

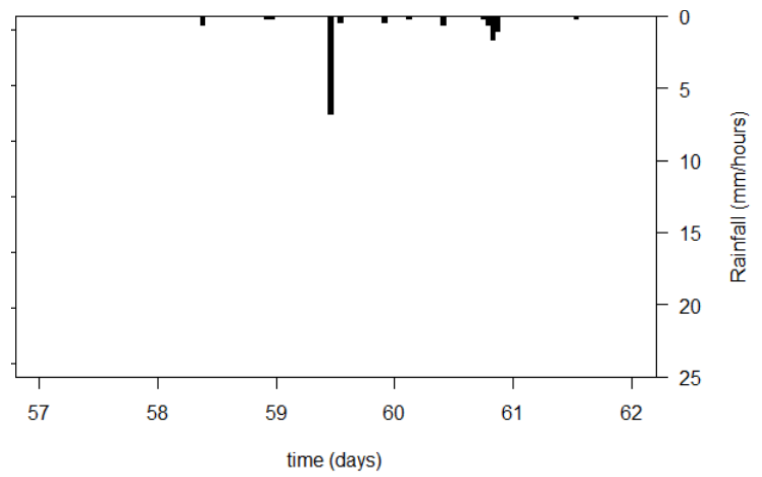

Figure 1: Rainfall data ( $\mathrm{mm} /$ hour) 


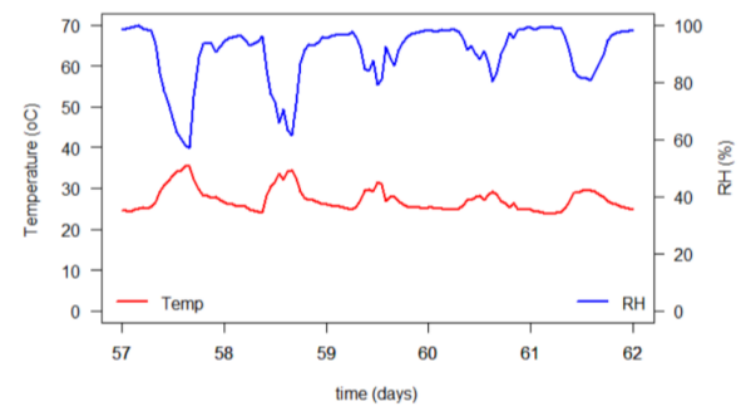

Figure 2:Temperature, RH, Solar radiation of Pantai Mas Estate, Pundu, Central Borneo

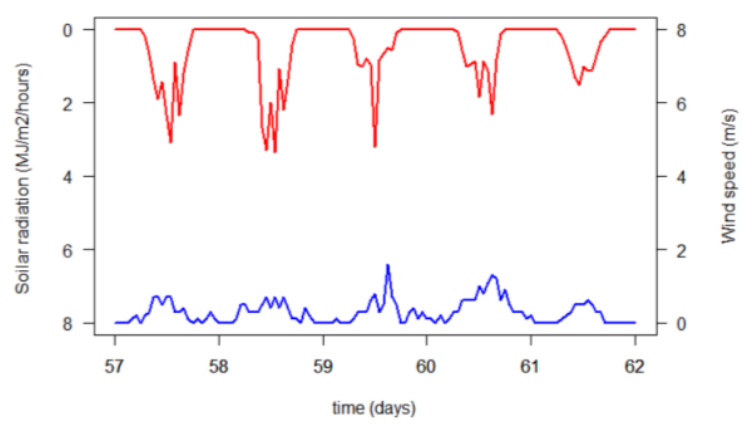

Figure 3: Wind speed of Pantai Mas Estate, Pundu, Central Borneo

\subsection{The model boundary condition}

The oil palm water balance model was built by assuming several boundary condition below:

1. Specific condition of each soil types;

- Ultisol ; a soil which has same amount of sand, silt and dust in the soil composition; Ks value is $10.31 \mathrm{~cm} /$ hour with the condition of groundwater contribution and initial water table is $200 \mathrm{~cm}$;

- Spodosol ; a soil texture is dominated with $89 \%$ of sand; Ks value is $36 \mathrm{~cm} /$ hour with specific condition of impermeable spodic layer that prevent drainage/ percolation and/or groundwater recharge;

- Inceptisol ; a soil composition consist of sand and loam, Ks is $8.24 \mathrm{~cm} /$ hour. For this location, measured groundwater depth was more than $10 \mathrm{~m}$. Therefore for this soil type, it is assumed that there is no contribution from groundwater recharge.

2. Oil palm properties

At this phase of model development, the oil palm used is planted in 2004, with Kc optimum value of 1 . Oil palm root distribution proportion for all soil types is similar. The proportion is $3,2,1$ for each root zone (see Table 2).

\subsection{Structure of oil palm water balance model}

Diagram of oil palm water balance model describe the calculation process for each input data of climate, soil and crop properties which illustrated in Figure 4. 


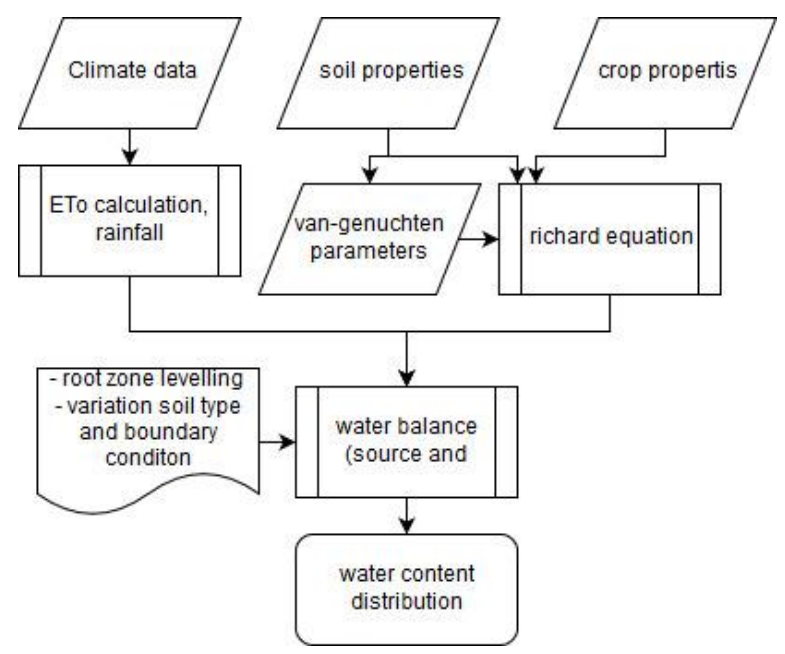

Figure 4: Oil palm water balance model

The distribution of water content in root zone was calculated based on the calculation steps as follows:

Water retention calculated by van Genuchten model [7]:

$m=1-\frac{1}{n}$

$$
\theta(h)=\theta_{r}+\frac{\theta_{s}-\theta_{h}}{\left(1+|\alpha h|^{n}\right)^{m}}
$$

Water capacity (Darcy law and Richards Equation) :

$C(h)=\frac{d \theta}{d h}=\frac{\alpha^{n}\left(\theta_{s}-\theta_{r}\right)(n-1)(|h|)^{n-1}}{\left[1+(\alpha|h|)^{n}\right]^{2-1 / n}}$

Hydraulic conductivity calculated by Muallem model [5]:

$K\left(S_{e}\right)=K_{s} \cdot S_{e}^{\lambda} \cdot\left(1-\left[1-S_{e}^{1 / m}\right]^{m}\right)^{2}$

$S$ degree of saturation [7]:

$S_{e}=\frac{\theta(h)-\theta_{r}}{\theta_{s}-\theta_{r}}$

Water flux by vertical flow of Richards Equation :

$J_{w}=-\left(K \frac{\partial h}{\partial z}-K\right)$

Richard equation (positive downward): 1D vertical flow

$\frac{\partial \theta}{\partial t}=-\frac{\partial J_{w}}{\partial z}-S$

$\frac{\partial \theta}{\partial t}=-\frac{\partial}{\partial z}\left(-\left(K \frac{\partial h}{\partial z}-K\right)\right)-S$

$\frac{\partial \theta}{\partial h}=C_{w}$

$C_{w} \frac{\partial h}{\partial t}=-\frac{\partial}{\partial z}\left(-\left(K \frac{\partial h}{\partial z}-K\right)\right)-S$

Notation : 
$\mathrm{K}=$ hydraulic conductivity $(\mathrm{cm} /$ hour $)$

$\mathrm{h}=$ water pressure head $(\mathrm{Pa})$

$\theta_{\mathrm{s}}=$ saturated water content $(\mathrm{cm} 3 / \mathrm{cm} 3)$

$\theta_{\mathrm{r}}=$ residual water content $(\mathrm{cm} 3 / \mathrm{cm} 3)$

$\square=$ air entry value $\left(\left(\mathrm{h}_{\mathrm{a}}=\square^{-1}\right)\right.$

$\lambda=$ pore-size distribution index

$\mathrm{C}(\mathrm{h})=$ water capacity

$\mathrm{Se}=$ effective saturation / degree saturation

$\mathrm{n}=$ curve gradient

$\mathrm{m}=$ empirical parameters

$\mathrm{JW}=$ total flux $(\mathrm{cm} / \mathrm{hour})$

$\mathrm{S}=$ sink factor, root water uptake/ accumulative actual evapotranspiration $(\mathrm{cm} / \mathrm{hour})$

\section{RESULT AND DISCUSSION}

\subsection{Evapotranspiration}

The ETo (evapotranspiration reference, $\mathrm{mm} /$ hours) and cumulative Eto $(\mathrm{cm})$ are calculated using Penman Montheit equation [9-11] by using climate input data. Figure 5 shows that, ETo value during night time and day time is 0 and maximum value between $0.4-0.9 \mathrm{~mm} /$ hours, respectively.
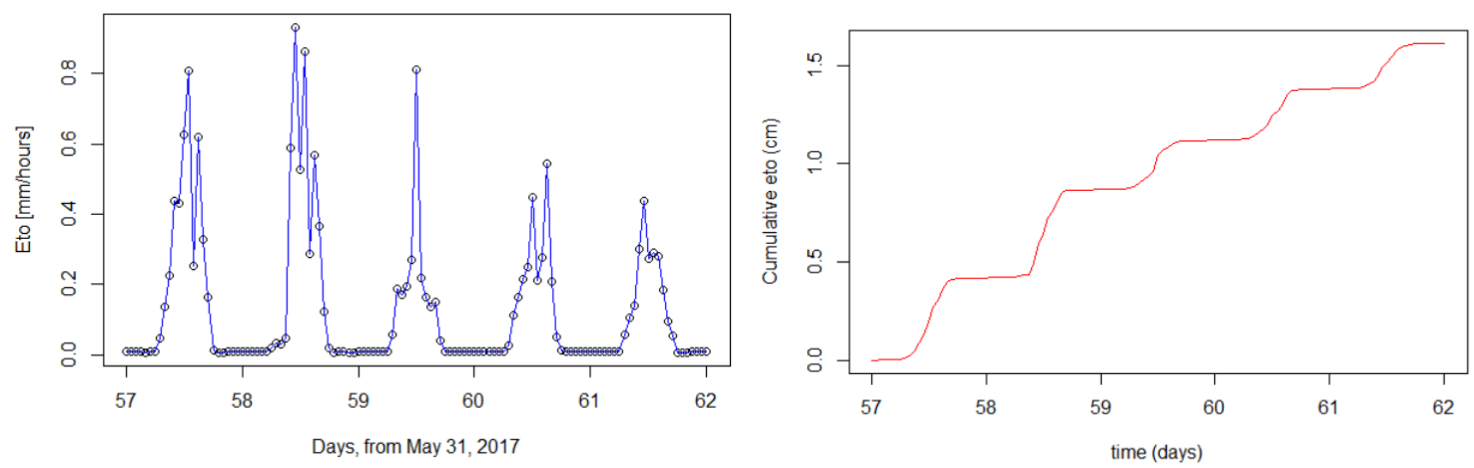

Figure 5: ETo (mm/ hour) and Cumulative ETo $(\mathrm{cm})$

\subsection{Infiltration flux, capillary flux and drainage flux}

The variation of soil types and its initial condition are utilized as input data in oil palm water balance model to attain cumulative infiltration flux, cumulative capillary flux, cumulative drainage flux, and also water content $(\mathrm{cm} 3 / \mathrm{cm} 3)$. Input data was processed every our within 120 hours and in 3 layers of root zone. Cumulative infiltration flux $(\mathrm{cm})$ from the three soil types can be seen in Figure 6 . The difference of Ks value between three soils has no significant impact in infiltration flux. This might due to relatively low rainfall data input, and some similar value of parameters such as plant characteristics condition, plant age (10 years) with optimum Kc of 1 and distribution of root density. 


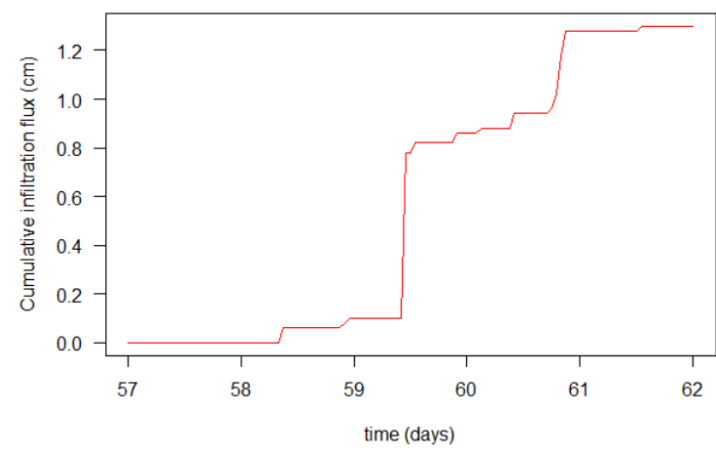

(a), Ks $=8.25$

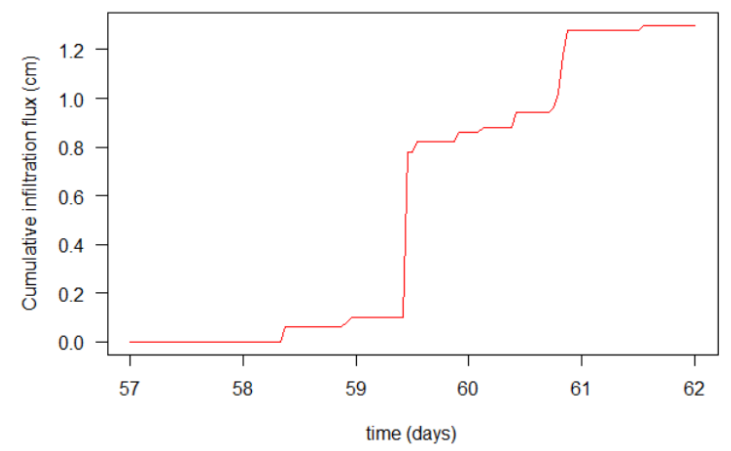

(b), Ks $=36$

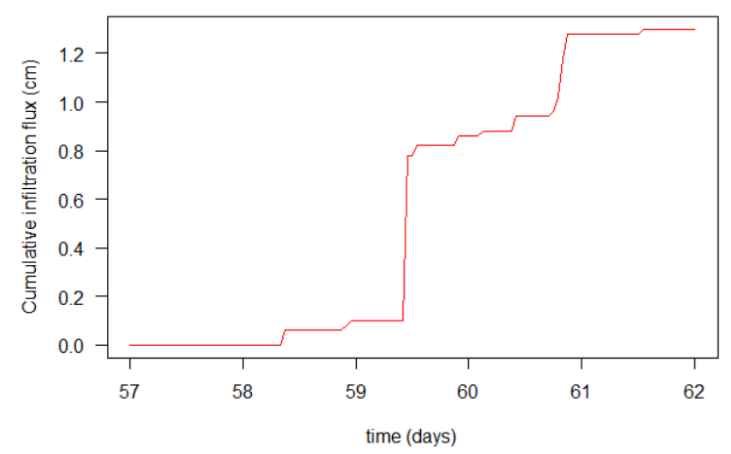

(c), $\mathrm{Ks}=10$

Figure 6: Cumulative infiltration flux ( $\mathrm{cm}$ ) of (a) inceptisol -free drainage, (b) spodosol - no flux bottom, (c) ultisol - groundwater

Figure 7 shows cumulative capillary flux $(\mathrm{cm})$ of oil plant from three soil types. For inceptisol and spodosol soil, cumulative capillary flux is 0 (zero), it means that there is no groundwater recharge. The absence of groundwater recharge for inceptison and spodosol soil is due to very deep groundwater table of more than $10 \mathrm{~m}$ in rainy reason (field observation result) and due to existence impermeable spodic layer. To the contrary, water table depth of approximately $200 \mathrm{~cm}$ from soil surface has a potential to create capillary flux as shown in Figure 7.c.

Other water balance parameter, cumulative drainage flux, is shown in Figure 8. There is no drainage flux in spodosol soil that caused by spodic layer that prevent up flow of capillary flux. While in inceptisol soil, the absence of capillary flux effect free drainage flux accumulation that ranges from $1 \mathrm{~cm}$ to $20 \mathrm{~cm}$ as a response of observation data input. Figure 8 (a), oil palm with utisol soil type, shows opposite flow direction to capillary flux that caused increase of cumulative drainage flux. As soil water content reach saturated condition up to point $3 \mathrm{~cm}$, drainage flux is zero due to capillary flux. 


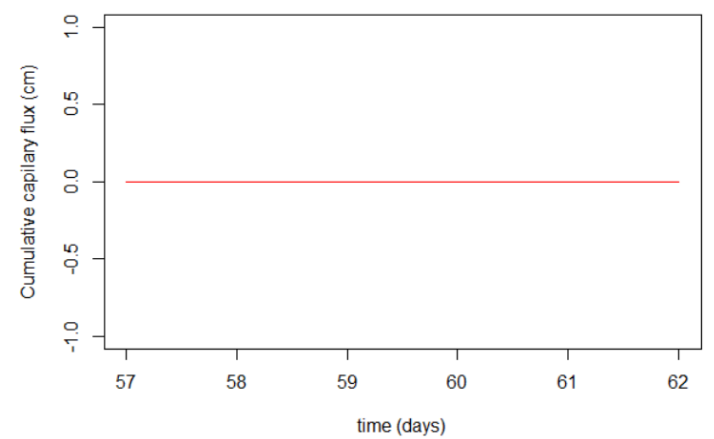

(a)

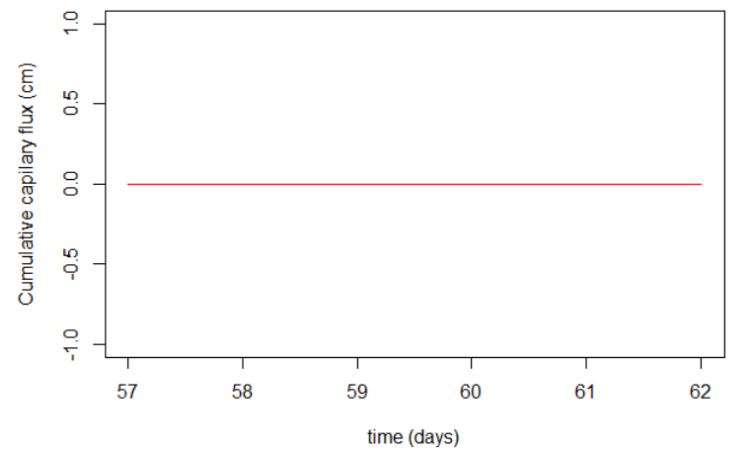

(b)

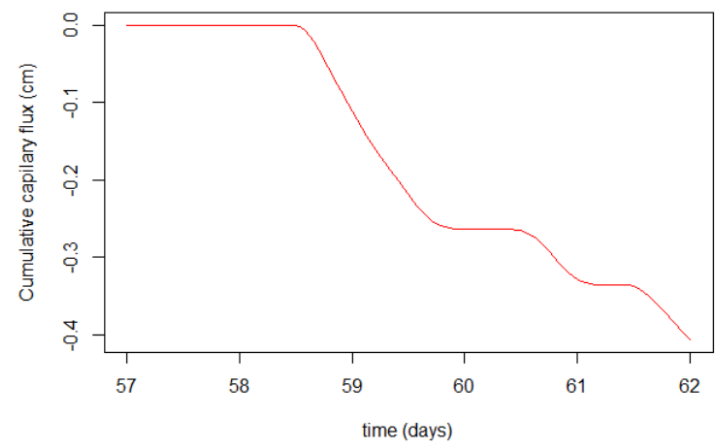

(c)

Figure 7: Cumulative capillary flux (cm) of (a)inceptisol - free drainage, (b) spodosol - no flux bottom, (c) ultisol - groundwater

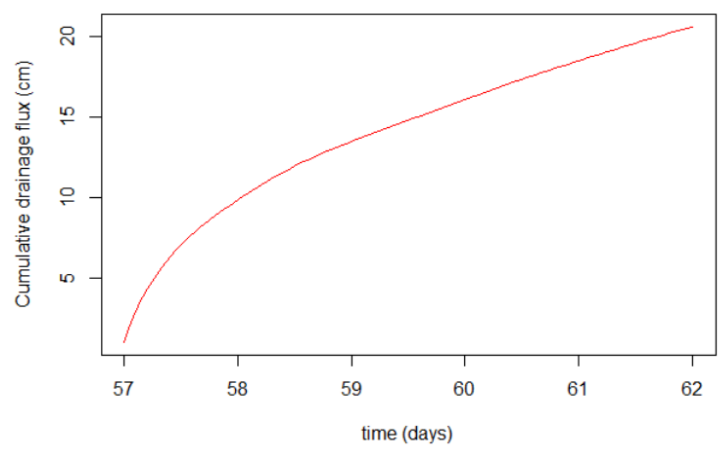

(a) 


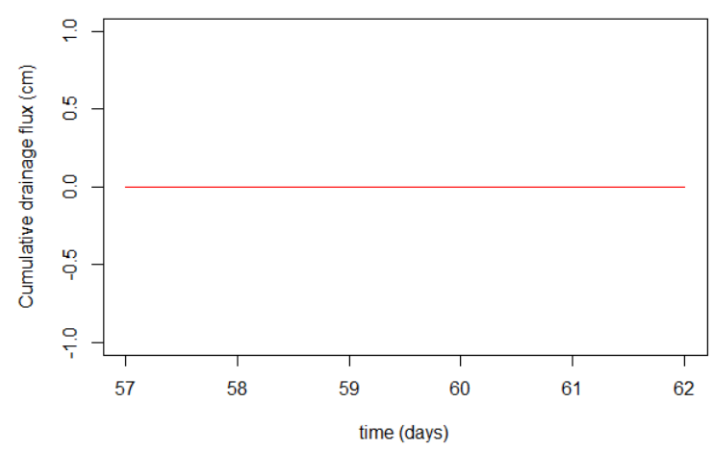

(b)

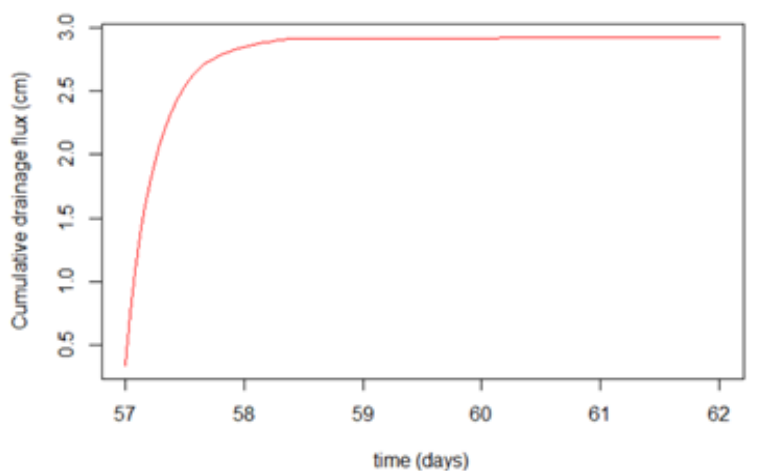

(c)

Figure 8: Cumulative drainage flux $(\mathrm{cm})$ of (a)inceptisol -free drainage, (b) spodosol - no flux bottom, (c) ultisol - groundwater

\subsection{Water content distribution model}

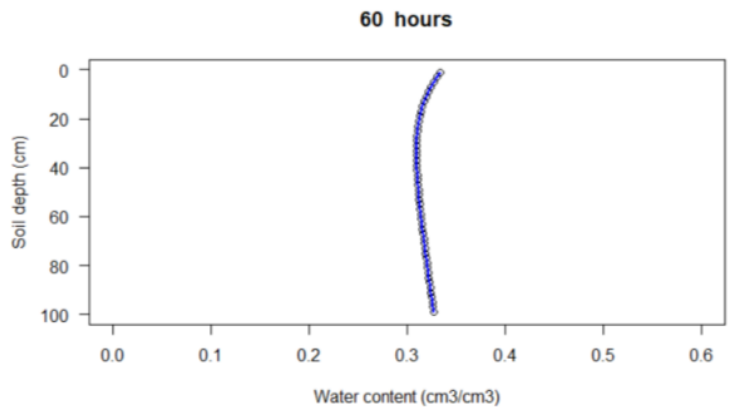

60 hours

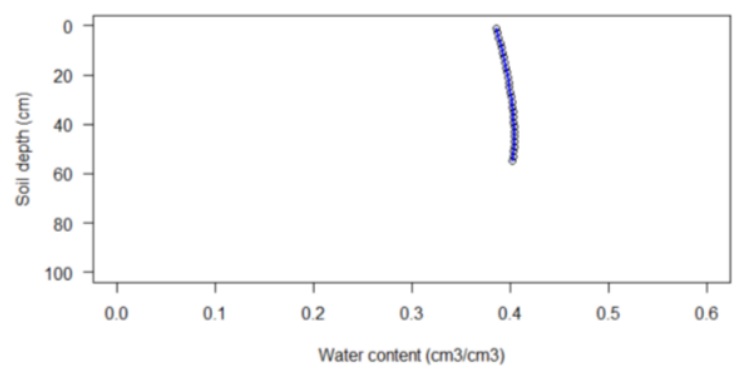

121 hours

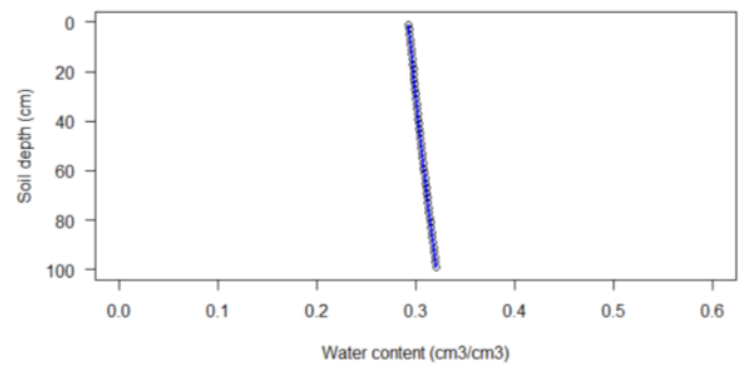

(a)

121 hours

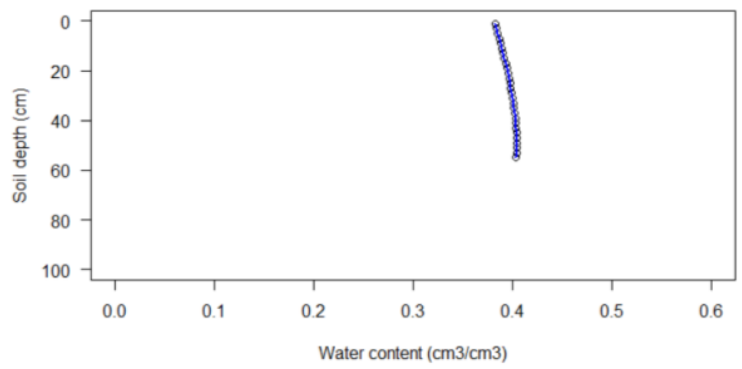

(b) 

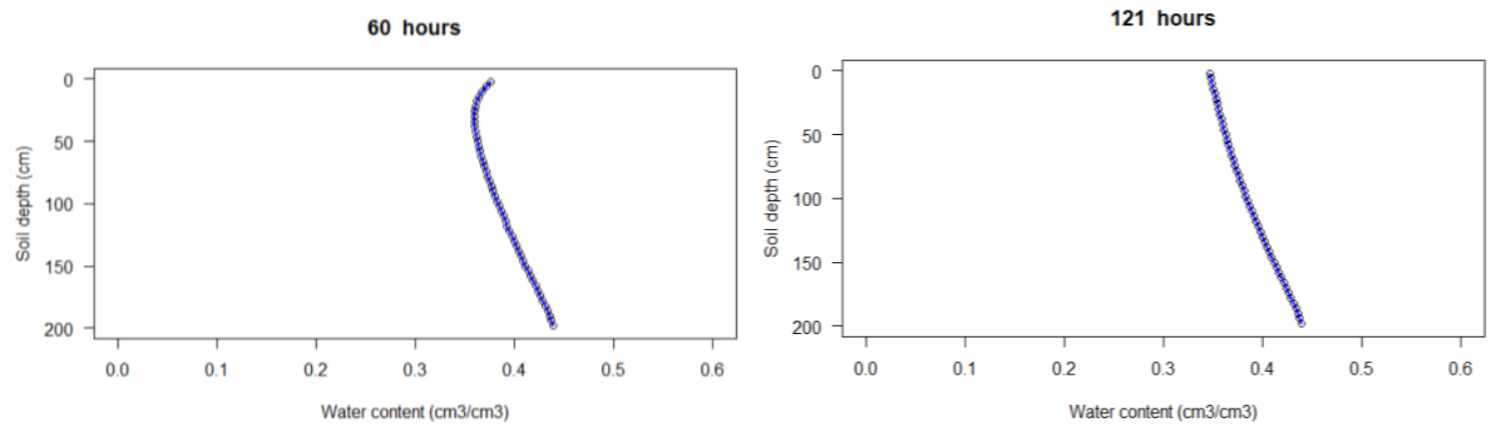

(c)

Figure 9: Soil depth vs Water content (a)inceptisol -free drainage, (b) spodosol - no flux bottom, (c) ultisol - groundwater

Data input of climate, soil types and oil palm plant characteristics are utilized to model the water content. Figure 9 shows changes of water content every hour within soil depth variation of $0-100 \mathrm{~cm}$, 0-60 $\mathrm{cm}$ and 1-200 $\mathrm{cm}$ for inceptisol, spodosol and ultisol soil, respectively. Water content at 60 and 121 hour are presented in Figure 9. During rainfall occurrence, water content is increasing. Water content is changing for ultisol soil where groundwater recharge occurs. It indicated by the curve movement to the down right direction.

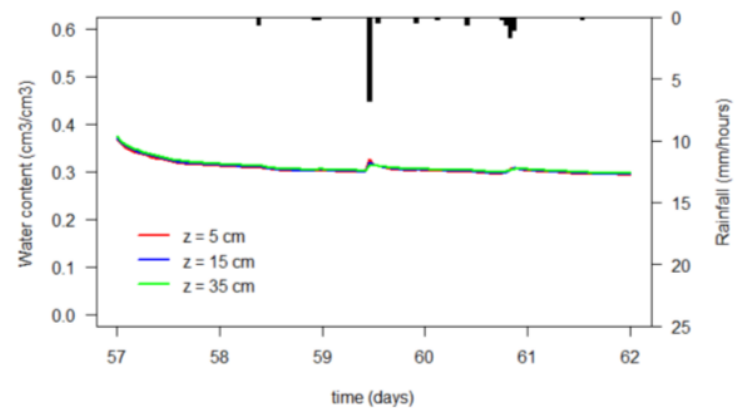

(a)

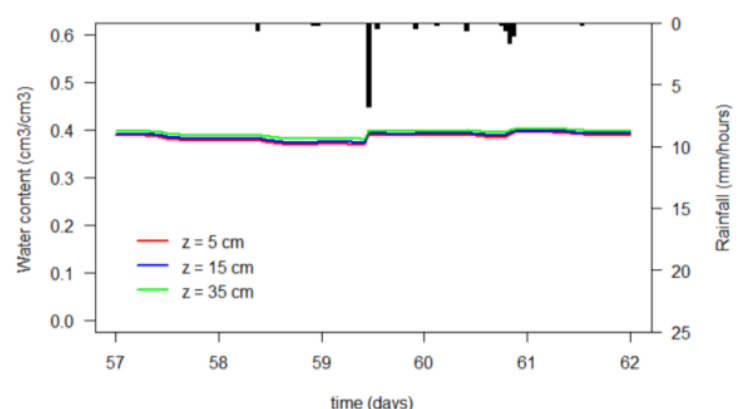

(b) 


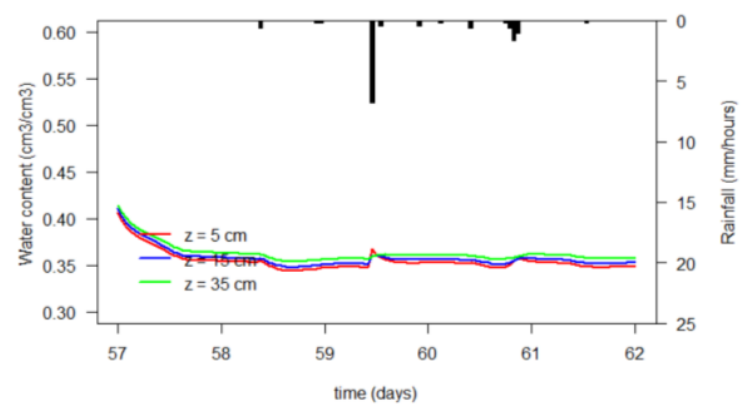

(c)

Figure 10: Water content distribution in 3 zone (a)inceptisol -free drainage, (b) spodosol - no flux bottom, (c) ultisol - groundwater

In order to analyze water use for each root zone of oil plant, a preliminary study of root distribution was performed. The study proposed 3 (three) root zones for each soil types (see Table 2).

Table 2:Root zone levelling for oil palm on inceptisol, spodosol and ultisol

\begin{tabular}{cccc}
\hline Root Zone & & Depth $(\mathrm{cm})$ & \\
\cline { 2 - 4 } & Inceptisol & Spodosol & Ultisol \\
\hline Zone 1 & 15 & 5 & 15 \\
Zone 2 & 45 & 15 & 45 \\
Zone 3 & 90 & 35 & 90 \\
\hline
\end{tabular}

Simulation model result calculated water content along the soil depth. Then, it was differentiated to water content distribution for each root zone from Table 2. The water content distribution was shown in Figure 10.

\section{CONCLUSION}

The work presented herein is a first step to develop a robust model of oil palm water balance. The result of the model showed each water balance parameter calculation consist of evapotranspiration reference, infiltration, drainage and capillary flux. This calculation by Richard equation resulted the simulation of soil water content in three different soil type ; inceptisol, spodosol and ultisol in 3 root zone.

In the next step, this model will be validate by the observed soil water content. The model will be developed by adding the procedure of water footprint calculation which consider the productivity and land area factors.

\section{ACKNOWLEDGEMENT}

This research was full supportedby Oil Palm Plantation Fund Management Agency, Indonesia. We also thank our colleagues from PT Bumitama Gunajaya Agro, Indonesia who provided the location, accommodation and the labours that greatly assisted the research. 


\section{REFERENCES}

[1] Yuan, F, Zhimming Lu.2005.Analytical Solutions for Vertical Flow in Unsaturated, Rooted Soils with Variable Surface Fluxes.Cleveland State University : America

[2] Philip, J.R.1957.The Theory of Infiltration, 4.Sorptivity and Algebraic infiltration Equations.Soil Sci. 84 : 257-264

[3] Gardner, W.R.1958.Some Steady State Solutions of the Unsaturated Moisture Flow Eequation with Applicaion to Evaporation from a Water Table, Soil Sci 85 : 228-232.

[4] Feddes, R.A, P.A.C.Raats.2004.Parameterizing the soil-water-plant root system, p, 95-141, In R.A. Feddes et al. (ed) Unsaturated zone modeling : Progress, challenges and applications. Wageningen UR Frontis Series.Kluwer Academic Publ.,Dordrecht, The Netherlands

[5] Mualem, Y., 1976. A new model for predicting the hydraulic conductivity ofunsaturated porous media. Water Resour. Res. 12 (3), 513-522.

[6] Richards, L.A.1931.Capillary Conduction of Liquids through Porous Mediums. Physics 1 : 318333

[7] Van Genuchten, M.T., 1980. A closed-form equation for predicting the hydraulicconductivity of unsaturated soils. Soil Sci. Soc. Am. J. 44 (5), 892-898.

[8] Van Genuchten MT, Nielsen DR. 1985. On describing and predicting the hydraulic propertis of unsaturated soils. Annales Geophysicae. 0755 0685/85/05. EGS-Gauthier-Villars.

[9] Allen, R.G., Pereira, L.S., Raes, D., and Smith, M. 1998 Crop evapotranspiration: Guidelines for computing crop water requirements, FAO Irrigation and Drainage Paper 56, Food and Agricultural Organization,Rome, Italy.

[10] FAO. 1999. Irrigation in Asia in figure, Water Reports 18, Food and Agricultural Organization, Rome, Italy.

[11] FAO. 2006. Irrigation and Drainage Paper. "Crop Evapotranspiration. Water Resources," Development and Management Service, Rome, Italy. 